\title{
CHANGES IN SOIL CHEMICAL ATTRIBUTES AND NUTRITION OF Anadenanthera colubrina AND Eucalyptus CLONE UNDER NATURAL FERTILIZERS AND BIOCHAR
}

\author{
Emmanoella Costa Guaraná Araujo ${ }^{* *}$, José Antônio Aleixo da Silva² ${ }^{2}$ Fernando José Freire ${ }^{3}$, Rinaldo Luiz \\ Caraciolo Ferreira ${ }^{4}$, Thiago Cardoso Silva ${ }^{5}$

\begin{abstract}
1ะUniversidade Federal do Paraná, Pós-Graduação em Engenharia Florestal, Curitiba, Paraná, Brasil - manuguarana @ gmail.com 2Universidade Federal Rural de Pernambuco, Departamento de Ciência Florestal, Recife, Pernambuco, Brasil - jaaleixo@uol.com.br ${ }^{3}$ Universidade Federal Rural de Pernambuco, Departamento de Agronomia, Recife, Pernambuco, Brasil - fernando.freire@ufrpe.br ${ }^{4}$ Universidade Federal Rural de Pernambuco, Departamento de Ciência Florestal, Recife, Pernambuco, Brasil - rinaldo.ferreira@ufrpe.br ${ }^{5}$ Universidade Federal do Paraná, Pós-Graduação em Engenharia Florestal, Curitiba, Paraná, Brasil - thiagocardoso.pe @ gmail.com
\end{abstract}

Received for publication: 30/04/2020 - Accepted for publication: 12/04/2021

\begin{abstract}
Resumo
Mudanças nos atributos químicos do solo e nutrição de Anadenanthera colubrina e clone de Eucalyptus sob fertilizantes naturais e biochar. O estudo teve por objetivo avaliar mudanças nos atributos químicos do solo e a nutrição de Anadenanthera colubrina e de um clone de Eucalyptus sob diferentes fontes de adubação, utilizando sedimentos de reservatórios (SR), sedimentos de piscicultura (SP) e biocarvão (BC) na região semiárida do Brasil. Após aplicação dos tratamentos, foram amostradas as folhas e solo do clone de Eucalyptus e A. colubrina. As folhas foram coletadas para análise nutricional e solo para análise mineral e de fertilidade. Os teores de $\mathrm{K}^{+}$e $\mathrm{P}$ no solo foram influenciados pelos fertilizantes naturais, e o biocarvão aumentou o teor de C. O plantio de A. colubrina reduziu os níveis de $\mathrm{K}^{+}$e $\mathrm{P}$ do solo, e o clone de Eucalyptus, o teor de $\mathrm{Mg}^{2+}$. Os SP foi responsável por aumentar a disponibilidade de $\mathrm{P}$ para ambas as espécies, sendo uma boa opção para uso em solos naturalmente pobres em P. A A. colubrina apresentou os maiores teores de N, P, K e Ca, sugerindo alta demanda dessa espécie por esses nutrientes. $\mathrm{O}$ clone de eucalipto era mais exigente em $\mathrm{Mg}$, sugerindo que seu cultivo fosse realizado em solos ricos em $\mathrm{Mg}^{2+}$. O uso de SR e SP é importante para aumentar o crescimento de espécies florestais em regiões semiáridas, e esse manejo é recomendado nas políticas de desmatamento dessas regiões.

Palavras-chave: fertilidade do solo; nutrição florestal; matéria orgânica; ciclagem biogeoquímica
\end{abstract}

\section{Abstract}

This study aimed to evaluate changes in soil chemical attributes and nutrition of Anadenanthera colubrina and a Eucalyptus clone under fertilization using reservoir sediment (RS), fish farming sediment (FFS) and biochar (BC) in the semi-arid region of Brazil. The Eucalyptus clone and A. colubrina leaves and soil were sampled after applying treatments. Leaves were collected for nutritional analysis and soil for mineral and fertility analyses. The $\mathrm{K}^{+}$and $\mathrm{P}$ concentration in the soil were influenced by the natural fertilizers, and the biochar increased the $\mathrm{C}$ content. The A. colubrina planting reduced the soil $\mathrm{K}^{+}$and $\mathrm{P}$ levels, and the Eucalyptus clone cultivation reduced the $\mathrm{Mg}^{2+}$ content. The FFS was responsible for increasing $\mathrm{P}$ availability in both $A$. colubrina and the Eucalyptus clone, being a good option for use in soils which are naturally poor in P. A. colubrina presented the highest N, P, K and Ca levels, suggesting high demand of this species for these nutrients. The Eucalyptus clone was more demanding for $\mathrm{Mg}$, suggesting that its cultivation should be done in soils rich in $\mathrm{Mg}^{2+}$. The use of RS and FFS is important to increase the growth of forest species in semi-arid regions, and this management is recommended in the deforestation policies of these regions.

Keywords: soil fertility; forest nutrition; organic matter; biogeochemical cycling

\section{INTRODUCTION}

The elements circulate in nature in a constant and balanced way and the nutrients which compose the vegetal biomass generally return to the abiotic environment by senescent material falling after its fragmentation, decomposition, and mineralization. The search for knowledge on the self-sustainability of ecosystems is constant, indispensable and increasing regarding nutrient cycling, especially in regions where rain scarcity is a limiting factor in the absorption of nutrients (ALBUQUERQUE et al., 2018). Therefore, only a soil fertility evaluation is insufficient to evaluate a plant's nutritional status. Thus, it is crucial to consider the content and type of nutrients, mainly in the plants' leaf component.

Knowledge on nutrient content in the phytomass and how this material returns to the soil is not only fundamental for adequate management of the forest production, but also to help reduces costs and environmental impacts as a consequence of reducing the amount of chemical fertilization used. Forest biomass formation contributes to translocating nutrients present in the lower soil layers, being absorbed by the plants' deep roots and returned by senescent plant material, and is essential for the natural maintenance of ecosystems (GAUTAM; MANDAL, 2018). Nutrient exportation from soils is relatively higher in regions with commercial plantations. 
Thus, management needs to consider leaving the exploitation residues in the field to improve soil fertility and contribute to maintaining the nutrient cycle (NANDWA; BEKUNDA, 1998).

Measuring and monitoring the nutrient content in the leaves is important, because it can indirectly provide information on soil fertility (SCHROTH; SINCLAIR, 2003). This knowledge can also contribute to increasing the financial return by reducing the costs of chemical fertilizers (TEIXEIRA et al., 2017a). Reforestation with fastgrowing species appears as an alternative to mitigate the use of natural vegetation in order to meet the demand for timber and non-timber forest products. However, such species are generally grown on low fertility soils, requiring additional nutrient supplementation to achieve the desired yield. Fast growing species (i.e. Eucalyptus sp.) have great importance in the industrial sector, however there is still little knowledge about the influence of forest management and site quality nutrient cycling (GONZÁLEZ-GARCÍA et al., 2016), especially in semi-arid regions. In this context, Anadenanthera colubrina has important medicinal properties and economic use for the semi-arid region due to the high content of tannins found in its bark, being used in treating wounds, colds, cough, burns, boils, colic, in addition to leather tannin (ARAÚJO et al., 2008).

Knowing how nutrients are absorbed by each commercial species or their contribution to nutrient cycling can contribute to research on the strategies used by plants to adapt to low rainfall environments, in turn contributing to increased forest productivity, especially with genetic breeding programs. Replacing nutrients in an organic form favors reducing environmental and water pollution, since organic waste which can also generate pollution is reused and chemicals are no longer applied to plantations, in addition to contributing to the increase in productivity levels.

Our hypothesis is that different sources of natural fertilizers and biochar with different $\mathrm{C} / \mathrm{N}$ ratios can improve the soil chemical attributes and increase the nutrition of the species. Natural fertilizers with lower $\mathrm{C} / \mathrm{N}$ ratios can nourish plants for a shorter time and biochar can prevent nutrient losses by leaching, providing more gradual and balanced nutrition in the longer-term, and increase the natural fertility. Therefore, this study aimed to evaluate changes in the soil chemical attributes and performance of Anadenanthera colubrina and a Eucalyptus clone under fertilization using reservoir sediment, fish farming sediment and biochar residues in the semi-arid region of Brazil.

\section{MATERIAL AND METHODS}

\section{Study area}

The experiment was established in 2014 at the Experimental Station of the Agricultural Research Institute of Pernambuco (Instituto de Pesquisa Agronômica de Pernambuco - IPA) in the semi-arid region of Pernambuco (Brazil). The region's climate is semiarid (BSh') according to the Köppen classification, with average annual precipitation of $507 \mathrm{~mm}$ and average temperature of $24.7^{\circ} \mathrm{C}$ (ALVARES et al., 2013). Soils in the region are Entisols (Fluvents) (SOIL SURVEY STAFF, 2014) and chemically characterized up to $90 \mathrm{~cm}$ of effective depth (Table 1). The vegetation in the region is composed by Steppe Savannah, or Northeast Brazilian Caatinga (IBGE, 2012).

Table 1. Soil chemical attributes and particle size distribution of the experimental area.

Tabela 1. Atributos químicos do solo e distribuição granulométrica da área experimental.

\begin{tabular}{|c|c|c|c|c|c|c|c|c|c|c|c|c|c|}
\hline $\begin{array}{c}\text { Depth } \\
(\mathrm{cm})\end{array}$ & $\begin{array}{l}\mathrm{pH}^{(1)} \\
\left(\mathrm{H}_{2} \mathrm{O}\right)\end{array}$ & $\mathrm{Ca}^{2+(2)}$ & $\mathrm{Mg}^{2+(2)}$ & $\begin{array}{c}\mathrm{K}^{+(3)} \\
-(\mathrm{cmo}\end{array}$ & $\begin{array}{l}\mathrm{Na}^{+(3)} \\
\left.\mathrm{ckg}^{-1}\right)\end{array}$ & $\mathrm{Al}^{3+(2)}$ & $(\mathrm{H}+\mathrm{Al})^{(4)}$ & $\mathrm{SB}^{(5)}$ & $\begin{array}{l}\mathrm{CEC}^{(6)} \\
-(\%)\end{array}$ & $\mathrm{V}^{(7)}$ & $\begin{array}{c}\mathrm{P}^{(3)} \\
\left(\mathrm{mg} \mathrm{m}^{-3}\right)\end{array}$ & $\begin{array}{l}\text { Sand Silt } \\
\quad\left(\mathrm{g} \mathrm{kg}^{-1}\right.\end{array}$ & Clay \\
\hline $0-30$ & 5.8 & 4.0 & 0.9 & 0.5 & 0.1 & 0.0 & 1 & 5.5 & 7.0 & 78.6 & 51.0 & $616 \quad 261$ & 123 \\
\hline $30-60$ & 6.0 & 4.3 & 0.9 & 0.2 & 0.1 & 0.0 & 0.9 & 5.5 & 6.4 & 85.9 & 37.7 & $603 \quad 256$ & 141 \\
\hline $60-90$ & 6.3 & 4.8 & 1.1 & 0.2 & 0.2 & 0.0 & 0.8 & 6.3 & 7.1 & 88.7 & 37.4 & 230 & 150 \\
\hline
\end{tabular}

${ }^{(1)}$ Soil solution (1:2.5); ${ }^{(2)} \mathrm{Ca}^{2+}, \mathrm{Mg}^{2+}$, and $\mathrm{Al}^{3+}$ were extracted using $\mathrm{KCl} 1.0 \mathrm{~mol} \mathrm{~L}{ }^{-1}$ and determined through titration; ${ }^{(3)} \mathrm{K}^{+}, \mathrm{Na}^{+}$and $\mathrm{P}$ were extracted using Mehlich-1; $\mathrm{P}$ dosage was by the $\mathrm{KI}+\mathrm{H}_{2} \mathrm{O}_{2}$ method and determined through UV-VIS spectrophotometry. $\mathrm{K}^{+}$, and $\mathrm{Na}^{+}$through flame photometry; ${ }^{(4)}$ Potential acidity was extracted with a $\mathrm{Ca}\left(\mathrm{C}_{2} \mathrm{H}_{3} \mathrm{O}_{2}\right)_{2}$ solution $0.5 \mathrm{~mol} \mathrm{~L}^{-1}$ and determined through titration; ${ }^{(5)}$ Sum of bases; ${ }^{(6)}$ Cation exchange capacity; ${ }^{(7)}$ Base saturation; All analyses were performed according to the methodologies described by Teixeira $e t$ al. (2017b).

\section{Experiment establishment}

The plantings were cultivated at $3 \mathrm{~m} \times 2 \mathrm{~m}$ spacing with four treatments established in all arrangements: two natural fertilizer sources and one soil conditioner, being: reservoir sediment, fish farming sediment and biochar (produced from the remaining P. Juliflora), and control (no fertilization). The experiment had four replicates with plots represented by 28 trees in a completely randomized design. All fertilizers and biochar were applied in the

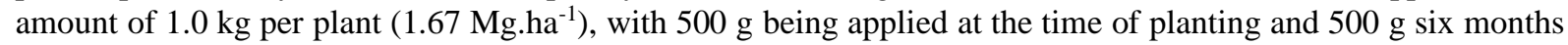
after.

Leaf and soil samples were collected 41 months after planting. Thus, 32 samples were evaluated, 16 of A. colubrina and 16 of Eucalyptus clones. The natural fertilization sources and biochar were chemically 
characterized before application (Table 2). This characterization will serve as a parameter to evaluate the effect of treatments applied 41 months after planting on the chemical properties of the soil, taking the treatment which did not receive fertilization (control) as a parameter.

Table 2. Chemical analysis of the natural fertilizers and biochar used in the experiment.

Tabela 2. Análise química dos fertilizantes naturais e biocarvão utilizados no experimento.

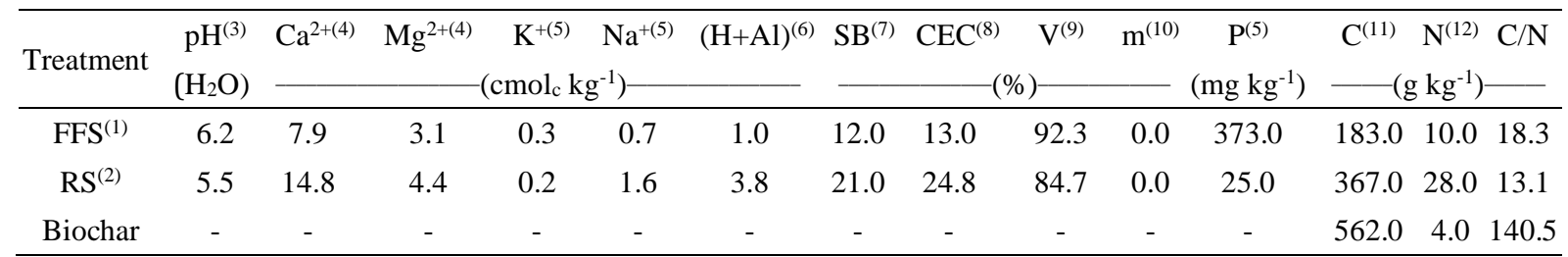

${ }^{(1)}$ Fish farming sediment; ${ }^{(2)}$ Resevoir sediment; ${ }^{(3)}$ Soil:solution $(1: 2.5) ;{ }^{(4)} \mathrm{Ca}^{2+}$ and $\mathrm{Mg}^{2+}$ were extracted using $\mathrm{KCl} 1.0 \mathrm{~mol} \mathrm{~L}^{-1}$ and determined through titration; ${ }^{(5)} \mathrm{K}^{+}, \mathrm{Na}^{+}$and $\mathrm{P}$ were extracted using $\mathrm{Mehlich}^{-1}$; $\mathrm{P}$ dosage was by the $\mathrm{KI}_{+} \mathrm{H}_{2} \mathrm{O}_{2}$ method and determined through UV-VIS spectrophotometry. $\mathrm{K}^{+}$, and $\mathrm{Na}^{+}$through flame photometry; ${ }^{(6)}$ Potential acidity was extracted with a $\mathrm{Ca}\left(\mathrm{C}_{2} \mathrm{H}_{3} \mathrm{O}_{2}\right)_{2}$ solution 0.5 mol $\mathrm{L}^{-1}$ and determined through titration; ${ }^{(7)} \mathrm{Sum}$ of bases; ${ }^{(8)}$ Cation exchange capacity; ${ }^{(9)}$ Base saturation; ${ }^{(10)}$ Aluminum saturation; ${ }^{(11)}$ Total organic carbon was carried out by oxidation by the $\mathrm{K}$ dichromate method; ${ }^{(12)} \mathrm{N}$ was determined through titration after steam distillation using the Kjeldahl method, according to Tedesco et al. (1995); All the other analyses were performed according to the methodologies described by Teixeira et al. (2017a).

\section{Soil chemical attributes}

Next, we collected soil samples at $30 \mathrm{~cm}$ depth to evaluate soil chemical attributes. Then, six trees from the center of the plot's useful area were chosen among the 10 individuals. The collection was performed opening the soil profile and collecting six simple samples to form a composite sample. Finally, this material was nutritionally analyzed and compared with the results of the $0-30 \mathrm{~cm}$ layer as shown in Table 1 .

\section{Nutrition assessment}

Next, 25 leaves in the middle third of the crown were collected for nutritional analysis, distributed throughout the perimeter of the 10 trees of the plot's useful area. The leaves were packed in paper bags and taken to forced aeration $65 \pm 5^{\circ} \mathrm{C}$ until reaching constant weight.

The leaf sample digestions were performed using a MarsXpress biodigestor with microwave heating and temperature control with a pressurizing tube. After cooling, the material was taken to a fume hood for dilution in a $25.0 \mathrm{ml}$ volumetric flask with distilled water. After dilution, they were stored in a plastic container and put under refrigeration for future analyzes. Total $\mathrm{N}$ content was determined based on the Kjeldahl steam drag method (TEDESCO et al., 1995). In turn, P content was determined from the colorimetric method of molybdo-vanadate, with the absorbance reading in a spectrophotometer at a wavelength of $470 \mathrm{~nm}$. The $\mathrm{K}$ was quantified by flame photometry. $\mathrm{Ca}$ and $\mathrm{Mg}$ readings were performed on an atomic absorption spectrophotometer (SILVA, 2009).

\section{Statistical analysis}

Statistical analyzes were performed using a factorial design and the means were compared by the Tukey test at the 5\% significance level, assessing whether there was significance in the main effects (separate factors) or in the interaction between them. A completely randomized design with two factors was used in order to compare the nutritional contents (Factor 1: two plant species - Eucalyptus clone and Anandenanthera colubrina; Factor 2: four soil treatments - reservoir sediment, fish farming sediment, biochar and no treatment). The data were analyzed using the Assistat 7.7 beta software program.

\section{RESULTS}

\section{Soil chemical attributes}

The $\mathrm{Mg}^{+2}, \mathrm{~K}^{+}$and $\mathrm{P}$ contents of the soil differed statistically between the plantations evaluated in this study (Table 3 ). Eucalyptus clone cultivation reduced $\mathrm{Mg}^{+2}$ content and A. colubrina cultivation reduced $\mathrm{K}^{+}$and $\mathrm{P}$ content of the soil, suggesting that the Eucalyptus clone is more demanding for $\mathrm{Mg}^{+2}$ and $A$. colubrina is more demanding for $\mathrm{K}^{+}$and $\mathrm{P}$. 
Table 3. Soil chemical attributes after treatment applications.

Tabela 3. Atributos químicos do solo após aplicação dos tratamentos.

\begin{tabular}{|c|c|c|c|c|c|c|c|c|c|c|}
\hline \multirow{2}{*}{ VARIABLES } & \multirow{2}{*}{ SPECIES } & \multicolumn{5}{|c|}{ TREATMENTS } & \multicolumn{3}{|c|}{ F-TEST } & \multirow{2}{*}{$\begin{array}{c}\mathrm{CV}^{(7)} \\
(\%)\end{array}$} \\
\hline & & Control & $\mathrm{FFS}^{(3)}$ & $\mathrm{RS}^{(4)}$ & Biochar & Average & $S^{(5)}$ & $\mathrm{T}^{(6)}$ & $\mathrm{S} \times \mathrm{T}$ & \\
\hline \multirow{3}{*}{$\begin{array}{c}\mathrm{pH} \\
\left(\mathrm{H}_{2} \mathrm{O}\right)\end{array}$} & Eucalyptus $^{(1)}$ & 6.1 & 6.1 & 6.0 & 5.9 & 6.0 & & & & \\
\hline & A. colubrina $a^{(2)}$ & 6.2 & 6.1 & 6.1 & 6.2 & 6.1 & $3.37^{\mathrm{ns}}$ & $1.19^{\mathrm{ns}}$ & $1.56^{\mathrm{ns}}$ & 1.90 \\
\hline & Average & 6.1 & 6.1 & 6.1 & 6.0 & - & & & & \\
\hline \multirow{3}{*}{$\begin{array}{c}\mathrm{Ca}^{2+} \\
\left(\mathrm{cmol}_{\mathrm{c}} \mathrm{dm}^{-3}\right)\end{array}$} & Eucalyptus & 3.3 & 3.5 & 3.3 & 3.0 & 3.3 & & & & \\
\hline & A. colubrina & 3.3 & 3.1 & 3.6 & 3.2 & 3.3 & $0.03^{\mathrm{ns}}$ & $0.66^{\mathrm{ns}}$ & $1.13^{\text {ns }}$ & 13.20 \\
\hline & Average & 3.3 & 3.3 & 3.4 & 3.1 & - & & & & \\
\hline \multirow{3}{*}{$\begin{array}{c}\mathrm{Mg}^{2+} \\
\left(\mathrm{cmol}_{\mathrm{c}} \mathrm{dm}^{-3}\right)\end{array}$} & Eucalyptus & 1.3 & 1.3 & 1.0 & 1.2 & $1.2 \mathrm{~b}$ & & & & \\
\hline & A. colubrina & 1.4 & 1.4 & 1.6 & 1.5 & $1.5 \mathrm{a}$ & $6.65^{*}$ & $0.09^{\mathrm{ns}}$ & $0.97^{\mathrm{ns}}$ & 22.48 \\
\hline & Average & 1.3 & 1.3 & 1.3 & 1.4 & - & & & & \\
\hline \multirow{3}{*}{$\begin{array}{c}\mathrm{K}^{+} \\
\left(\mathrm{cmol}_{\mathrm{c}} \mathrm{dm}^{-3}\right)\end{array}$} & Eucalyptus & 0.50 & 0.66 & 0.67 & 0.49 & $0.58 \mathrm{a}$ & & & & \\
\hline & A. colubrina & 0.43 & 0.54 & 0.49 & 0.58 & $0.46 \mathrm{~b}$ & $28.57^{* *}$ & $12.76^{* *}$ & $0.83^{\mathrm{ns}}$ & 12.25 \\
\hline & Average & $0.47 \mathrm{~B}$ & $0.60 \mathrm{~A}$ & $0.58 \mathrm{~A}$ & $0.44 \mathrm{~B}$ & - & & & & \\
\hline \multirow{3}{*}{$\begin{array}{c}\text { CEC } \\
\left(\mathrm{cmol}_{\mathrm{c}} \mathrm{dm}^{-3}\right)\end{array}$} & Eucalyptus & 6.0 & 6.4 & 6.7 & 5.8 & 6.2 & & & & \\
\hline & A. colubrina & 5.9 & 6.4 & 6.4 & 6.2 & 6.2 & $0.06^{\mathrm{ns}}$ & $0.97^{\mathrm{ns}}$ & $0.40^{\mathrm{ns}}$ & 10.97 \\
\hline & Average & 6.0 & 6.4 & 6.5 & 6.1 & - & & & & \\
\hline \multirow{3}{*}{$\begin{array}{c}\mathrm{V} \\
(\%)\end{array}$} & Eucalyptus & 81.7 & 93.9 & 81.3 & 80.6 & 81.9 & & & & \\
\hline & A. colubrina & 85.7 & 88.4 & 88.4 & 63.0 & 81.4 & $0.01^{\mathrm{ns}}$ & $1.54^{\mathrm{ns}}$ & $1.15^{\mathrm{ns}}$ & 18.56 \\
\hline & Average & 83.7 & 86.1 & 84.9 & 81.8 & - & & & & \\
\hline \multirow{3}{*}{$\begin{array}{c}\mathrm{P} \\
\left(\mathrm{mg} \mathrm{dm}^{-3}\right)\end{array}$} & Eucalyptus & 70.0 & 90.0 & 75.0 & 65.0 & $75.0 \mathrm{a}$ & & & & \\
\hline & A. colubrina & 55.0 & 70.0 & 60.0 & 55.0 & $60.0 \mathrm{~b}$ & $51.86^{* * *}$ & $3.86^{*}$ & $0.43^{\mathrm{ns}}$ & 8.39 \\
\hline & Average & $62.5 \mathrm{~B}$ & $80.0 \mathrm{~A}$ & $67.5 \mathrm{~B}$ & $60.0 \mathrm{~B}$ & - & & & & \\
\hline \multirow{3}{*}{$\begin{array}{c}\mathrm{C} \\
\left(\mathrm{g} \mathrm{kg}^{-1}\right)\end{array}$} & Eucalyptus & 8.9 & 8.9 & 9.0 & 11.5 & 9.6 & & & & \\
\hline & A. colubrina & 8.7 & 9.7 & 9.4 & 11.5 & 9.8 & $1.54^{\mathrm{ns}}$ & $40.69^{* *}$ & $1.30^{\mathrm{ns}}$ & 5.69 \\
\hline & Average & $8.8 \mathrm{~B}$ & $9.3 \mathrm{~B}$ & $9.2 \mathrm{~B}$ & $11.5 \mathrm{~A}$ & - & & & & \\
\hline
\end{tabular}

${ }^{(1)}$ Eucalyptus clone; ${ }^{(2)}$ Anadenanthera colubrina var. Cebil; ${ }^{(3)}$ Fish farming sediment; ${ }^{(4)}$ Resevoir sediment; ${ }^{(5)}$ Species; ${ }^{(6)}$ Treatments; ${ }^{(7)}$ Coeficient of variation. Similar averages followed by lower case letters in the rows and upper case in the columns do not differ by the Tukey test at $5 \%$ significance. $*$ and $* *$ significant at 5.0 and $1.0 \%$ significance by the F-test, respectively. ${ }^{\mathrm{ns}}$ not significant.

\section{Nutrition assessment}

Although the soil was rich in nutrients (Table 1), it was observed that fertilization sources interfered in the contents of some nutrients, as well as the different forest species. In addition to presenting differences in the $\mathrm{P}$ and $\mathrm{K}$ content because they are different species, the natural fertilization sources interacted with these different nutritional demands and interfered in the nutrition of the species (Table 4).

Table 4. Nutrient content in the leaves of the species after applying the treatments.

Tabela 4. Teor de nutrientes nas folhas das espécies após aplicação dos tratamentos.

\begin{tabular}{|c|c|c|c|c|c|c|c|c|c|c|}
\hline \multirow{2}{*}{ VARIABLES } & \multirow{2}{*}{ SPECIES } & \multicolumn{5}{|c|}{ TREATMENTS } & \multicolumn{3}{|c|}{ F-TEST } & \multirow{2}{*}{$\begin{array}{c}\mathrm{CV}^{(7)} \\
(\%)\end{array}$} \\
\hline & & Control & $\mathrm{FFS}^{(3)}$ & $\mathrm{RS}^{(4)}$ & Biochar & Average & $S^{(5)}$ & $\mathrm{T}^{(6)}$ & $S \times T$ & \\
\hline \multirow{3}{*}{$\begin{array}{c}\mathrm{N} \\
\left(\mathrm{g} \mathrm{kg}^{-1}\right)\end{array}$} & Eucalyptus $^{(1)}$ & 16.7 & 16.5 & 17.4 & 16.9 & $17.6 \mathrm{~b}$ & & & & \\
\hline & A. colubrina ${ }^{(2)}$ & 23.0 & 22.9 & 21.4 & 22.9 & $22.6 \mathrm{a}$ & $47.4^{* * *}$ & $1.3^{\mathrm{ns}}$ & $1.2^{\mathrm{ns}}$ & 10.2 \\
\hline & Average & 19.9 & 19.7 & 19.4 & 22.1 & - & & & & \\
\hline \multirow{3}{*}{$\begin{array}{c}\mathrm{P} \\
\left(\mathrm{g} \mathrm{kg}^{-1}\right)\end{array}$} & Eucalyptus & $3.9 \mathrm{bBC}$ & $4.8 \mathrm{bA}$ & $4.6 \mathrm{bAB}$ & $3.6 \mathrm{bC}$ & 4.2 & & & & \\
\hline & A. colubrina & $7.1 \mathrm{aB}$ & $10.3 \mathrm{aA}$ & $6.8 \mathrm{aB}$ & $6.4 \mathrm{aB}$ & 7.7 & $668.8^{* *}$ & $69.7^{* *}$ & $28.9^{* *}$ & 6.3 \\
\hline & Average & 5.5 & 7.5 & 5.7 & 5.0 & - & & & & \\
\hline \multirow{2}{*}{$\underset{\left(\mathrm{g} \mathrm{kg}^{-1}\right)}{\mathrm{K}}$} & Eucalyptus & $6.1 \mathrm{aA}$ & $6.4 \mathrm{aA}$ & $6.1 \mathrm{bA}$ & $5.1 \mathrm{bB}$ & 5.9 & & & & \\
\hline & A. colubrina & $6.2 \mathrm{aA}$ & $6.8 \mathrm{aA}$ & $6.7 \mathrm{aA}$ & $6.4 \mathrm{aA}$ & 6.5 & $23.6^{* * *}$ & $8.2^{* *}$ & $3.9^{*}$ & 5.7 \\
\hline \multirow{3}{*}{$\begin{array}{c}\mathrm{Ca} \\
\left(\mathrm{g} \mathrm{kg}^{-1}\right)\end{array}$} & $\frac{\text { Average }}{\text { Eucalyptus }}$ & $\begin{array}{l}6.2 \\
15.0\end{array}$ & $\frac{6.6}{15.6}$ & $\begin{array}{c}6.4 \\
-15.8\end{array}$ & $\begin{array}{r}5.7 \\
14.9\end{array}$ & $15.4 \mathrm{~b}$ & & & & \\
\hline & A. colubrina & 16.6 & 15.7 & 16.4 & 16.2 & $16.3 \mathrm{a}$ & $19.2^{* * *}$ & $1.4^{\mathrm{ns}}$ & $2.9^{\text {ns }}$ & 3.6 \\
\hline & Average & 15.8 & 15.7 & 16.1 & 15.5 & - & & & & \\
\hline \multirow{3}{*}{$\begin{array}{c}\mathrm{Mg} \\
\left(\mathrm{g} \mathrm{kg}^{-1}\right)\end{array}$} & Eucalyptus & 4.7 & 4.8 & 4.5 & 4.7 & $4.7 \mathrm{a}$ & & & & \\
\hline & A. colubrina & 2.5 & 2.4 & 2.5 & 2.4 & $2.5 \mathrm{~b}$ & $465.3^{* *}$ & $0.2^{\mathrm{ns}}$ & $0.5^{\mathrm{ns}}$ & 8.7 \\
\hline & Average & 3.6 & 3.5 & 3.5 & 3.6 & - & & & & \\
\hline
\end{tabular}

${ }^{(1)}$ Eucalyptus clone; ${ }^{(2)}$ Anadenanthera colubrina var. Cebil; ${ }^{(3)}$ Fish farming sediment; ${ }^{(4)}$ Resevoir sediment; ${ }^{(5)}$ Species; ${ }^{(6)}$ Treatments; ${ }^{(7)}$ Coeficient of variation. Similar averages followed by lower case letters in the rows and upper case in the columns do not differ by the Tukey test at $5 \%$ significance. $*$ and $* *$ significant at 5.0 and $1.0 \%$ significance by the F-test, respectively. ${ }^{\text {ns }}$ not significant.

The nutrient content found in the pure plantations follows the sequence: $\mathrm{N}>\mathrm{Ca}>\mathrm{K}>\mathrm{Mg}>\mathrm{P}$ for the Eucalyptus clone, and $\mathrm{N}>\mathrm{Ca}>\mathrm{P}>\mathrm{K}>\mathrm{Mg}$ for $A$. colubrina. The A. colubrina species presented higher nutrient 
content than the Eucalyptus clone, except for $\mathrm{Mg}$. The $\mathrm{N}$ content in the leaves showed that there was no interaction between the species and the soil treatment, while A. colubrina presented higher content. However, the treatments applied in the soil did not present a difference in the $\mathrm{N}$ content of the species when compared to the control (no fertilization).

\section{DISCUSSION}

\section{Soil chemical attributes}

The application of different sediments in the soils, including the biochar, influenced the concentration of the soils' nutritional contents, especially for K, P and C macronutrients (Table 3). Both reservoir and fish farming sediments increased soil $\mathrm{K}$ and $\mathrm{P}$ levels, and biochar increased $\mathrm{C}$ levels. Although $\mathrm{K}$ contents were already high in the topsoil (Table 1), they were increased by $4.5 \%$ on average due to sediment application when compared to the initial soil contents before applying the natural fertilizers. Sediments also increased by $44.6 \%$ in average $\mathrm{P}$ content of the soil (Tables 1 and 3) and differed from each other because the fish farming sediment had much more $\mathrm{P}$ than the reservoir sediment (Table 2). Sediment from fish farming tanks commonly has high $\mathrm{P}$ and $\mathrm{C}$ levels (SALAZAR; SALDANHA, 2007). Thus, the fish farming sediment could have further influenced soil P levels due to the high amounts of $\mathrm{P}$ in this sediment. However, it is possible that the $\mathrm{P}$ from the fish farming sediment may have been lost from the soil in a number of ways: precipitated due the high levels of Ca already existing in the soil (Table 1) and from the sediment itself (Table 2); complexed by biochar; leached due to the soil being very sandy (Table 1); and/or absorbed by plants.

In using residues from five different fish farming operations, all with nutrient amounts lower than the present study, Silva et al. (2017) verified that the use of this material was efficient in yellow passion fruit seedling production, being a good way to reuse the material and reduce the production costs. Theodoro et al. (2013) carried out fertility analyzes in the sediments and soils of the Tucuruí-PA reservoir and observed nutrient contents and organic matter with potential use as fertilizer. Even those elements found in quantities considered low were superior to the quantity present in the soil, therefore verifying its feasible use in agronomic production, in addition to the benefit of removing the sediment from the reservoir.

In addition to the availability of nutrients, the use of organic fertilization reduces the apparent density of the soil, increasing its porosity and consequently the water and nutrient availability to the plants (KIZITO et al., 2019). The $\mathrm{C}$ content was found in higher amount in the parcels that received the biochar treatment due to the material composition. Although not directly contributing to soil fertility, biochar is important for retaining water and nutrients (DUARTE et al., 2019). Biochar application is important to retain nutrients and allow their more efficient use over time in soils of high natural fertility, but very sandy as in this study (Table 1), and especially in forest crops.

\section{Nutrition assessment}

A. colubrina showed higher $\mathrm{N}$ content than the Eucalyptus clone, which is explained by the fact that the species is a legume and associates with bacteria capable of fixing atmospheric $\mathrm{N}_{2}$ (VEJAN et al., 2016). The different treatments applied to the soil were not enough to present significant differences in the $\mathrm{N}$ content of the species, which indicates that the soil already had sufficient nutrient content to meet the requirements of the individuals.

The Eucalyptus clone presented an average of $17.6 \mathrm{~g} \mathrm{~kg}^{-1}$ of $\mathrm{N}$ in the leaf fraction, while A. colubrina showed an average of $22.6 \mathrm{~g} \mathrm{~kg}^{-1}$ (Table 4). Studies carried out in the Caatinga environment presented mean values of $6.0 \mathrm{~g} \mathrm{~kg}^{-1}$ of the $\mathrm{N}$ in leaves of A. colubrina (ALVES et al., 2017; HOLANDA et al., 2015). This value differs considerably from the present study. However, it is not possible to know the age of the trees of the studies carried out by these authors because it is a natural environment. In addition, the A. colubrina individuals in this study are very young, not to mention that competition for water and nutrients is lower because of the homogeneous spacing. This fact led to younger plants having great potential to extract and recycle nutrients, because plants require more nutrients to form biomass during growth (LI et al., 2018).

A. colubrina showed higher P content in all treatments applied to the soil. However, when the treatments within each species were observed, the $\mathrm{P}$ content in the Eucalyptus clone cultivated with the fish farming and reservoir sediments stood out, as well as the $\mathrm{P}$ content in $A$. colubrina cultivated with the fish farming sediment (Table 4). Some factors such as the age of the individuals and the P available in the soil may have contributed to the values found, since the age of the individuals interferes in the nutrient content present in the biomass (Barbosa et al., 2019).

The Eucalyptus clone presented an average of $4.2 \mathrm{~g} \mathrm{~kg}^{-1}$ de $\mathrm{P}$ in the leaf fraction, while A. colubrina had $7.7 \mathrm{~g} \mathrm{~kg}^{-1}$ (Table 4). The values found are much higher than those in the literature, which may have occurred due to the large amount of $\mathrm{P}$ found in the soil prior to applying the treatments (Table 1), as well as the large amount of 
$\mathrm{P}$ in the sediments, especially from fish farming (Table 2). The application of the fish farming sediment provided the plants with a higher P value, followed by the reservoir sediment (Table 4).

In a study carried out in Eucalyptus dunni, Guimarães et al. (2015) found a $P$ value of $1.0 \mathrm{~g} \mathrm{~kg}^{-1}$ in the leaves, diverging from this study. Although the individuals were close in age in both studies, the amount of nutrients in the soil was very divergent. The $\mathrm{P}$ content in the superficial layer was $51 \mathrm{mg} \mathrm{dm}^{-3}$ in our study before receiving the treatments (Table 1), while the $P$ content in the study of the authors in the layer up to $20 \mathrm{~cm}$ was 2.3 $\mathrm{mg} \mathrm{dm}{ }^{-3}$.

The application of reservoir sediment and biochar incresed the K content in the Eucalyptus clone (Table 4). However, the biochar was the only natural fertilizer source which diverged from the others in the Eucalyptus clone, reducing nutrient content in the species. The control sample already had a satisfactory $\mathrm{K}$ amount because the soil already had a high $\mathrm{K}^{+}$content (Table 1). Moreover, the $\mathrm{K}^{+}$levels in the soil increased even more with the addition of fertilizer sources (Table 3). The nutrient absorption may have been lower for the Eucalyptus clone in the biochar treatment, which may have occurred due to the great mobility of this nutrient and the capacity of the biochar to retain the nutrients (LEHMANN, 2007).

The average $\mathrm{K}$ values found in each species were $5.9 \mathrm{~g} \mathrm{~kg}^{-1}$ for the Eucalyptus clone and $6.6 \mathrm{~g} \mathrm{~kg}^{-1}$ for $A$. colubrina. A study carried out by Vieira and Weber (2017) with eucalyptus seedlings using different substrates showed an average $\mathrm{K}$ value of $10.14 \mathrm{~g} \mathrm{~kg}^{-1}$, well above that found in this study. However, the individuals analyzed were 4 months old. The authors also justified the high value found because the $\mathrm{K}$ content in the culture substrate was also high. Similar results to that study were also found by Guimarães et al. (2015), finding a K value in the leaves of 48-month-old individuals of $5.9 \mathrm{~g} \mathrm{~kg}^{-1}$. Alves et al. (2017) carried out evaluations in a natural vegetation area and found a $\mathrm{K}$ content of $1.38 \mathrm{~g} \mathrm{~kg}^{-1}$ for A. colubrina; this value is lower than the results of this study, most likely because the species is in competition with others and the area has not been subjected to any soil treatment.

Another factor which may have interfered with the $\mathrm{K}$ absorption was the high content of $\mathrm{Ca}$ found in the leaves (Table 4), since although nutrient absorption especially depends on their concentration in the soil solution, there may be competition between cations in the same site of the root surface, causing the absorption of one of the nutrients to be inhibited by the other (FAGERIA, 2001).

A. colubrina also had the highest Ca content when compared to the Eucalyptus clone (Table 4). However, there was no difference between treatments among the fertilization sources. The mean $\mathrm{Ca}$ values found in each species were $15.4 \mathrm{~g} \mathrm{~kg}^{-1}$ for the Eucalyptus clone and $16.2 \mathrm{~g} \mathrm{~kg}^{-1}$ for A. colubrina (Table 4). Toledo et al. (2013) found $\mathrm{Ca}$ values of $16.5 \mathrm{~g} \mathrm{~kg}^{-1}$ in eucalyptus and recommended reduced fertilization with $\mathrm{Ca}$. This proves that the high $\mathrm{Ca}$ levels may have interfered in the $\mathrm{K}$ absorption, as previously discussed. In studying 18-month-old individuals, Viera et al. (2012) found a Ca content of $10.5 \mathrm{~g} \mathrm{~kg}^{-1}$, which is lower than this study. The authors recommend that the Ca content should be between $4.40 \mathrm{~g} \mathrm{~kg}^{-1}$ and $5.90 \mathrm{~g} \mathrm{~kg}^{-1}$, showing that there may be imbalance in relation to $\mathrm{Mg}$ above these values. On the other hand, Alves et al. (2017) found $4.1 \mathrm{~g} \mathrm{~kg} \mathrm{~g}^{-1}$ of Ca in the Caatinga regeneration area. This value is four times lower than the value found in this study for A. colubrina (Table 4). This can be explained by the fact that the soil had high Ca levels (Table 1), and A. colubrina was fertilized with Ca-rich sediments (Table 2). Additionally, there was no competition between species in A. colubrina planting as in the Caatinga regeneration areas.

$\mathrm{Mg}$ was the only nutrient which appeared in greater quantity in the Eucalyptus clone (Table 4). The mean $\mathrm{Mg}$ values found for the species were $4.7 \mathrm{~g} \mathrm{~kg}^{-1}$ for the Eucalyptus clone and $2.5 \mathrm{~g} \mathrm{~kg}^{-1}$ for A. colubrina. Guimarães et al. (2015) found lower values for eucalyptus individuals with ages close to this study $\left(2.5 \mathrm{~g} \mathrm{~kg}^{-1}\right)$, although the soil presented similar levels to those of the control in this research. Viera et al. (2012) found $2.7 \mathrm{~g} \mathrm{~kg}^{-1}$ content in 18-month-old Eucalyptus leaves, which is lower than in this study. However, the site's soil presented low $\mathrm{Mg}$ content compared to this study. Alves et al. (2017) also found smaller amounts for A. colubrina $\left(0.50 \mathrm{~g} \mathrm{~kg}^{-1}\right)$, which can be justified by the age of the individuals and low natural fertility of the soil.

A. colubrina generally presented higher nutrient content, since it is a pioneer species and therefore allocates more nutrients for its growth, creating adequate conditions for ecological succession (HOLANDA et al., 2015).

\section{CONCLUSIONS}

- Fertilizer sources and soil conditioner significantly interfere in the Eucalyptus clone and Anadenanthera colubrina plantations in semi-arid regions, serving as substitutes for chemical compounds;

- The $\mathrm{K}^{+}$and $\mathrm{P}$ contents of the soil were influenced by the natural fertilizers and the biochar increased the $\mathrm{C}$ content of the soil;

- The fish farming sediment was responsible for increasing $\mathrm{P}$ contents in the two species, and is recommended for soils which are naturally poor in P; 
- Anadenanthera colubrina presented the highest N, P, K and Ca levels, suggesting high demand of this species for these nutrients;

- The Eucalyptus clone was more demanding in Mg than Anadenanthera colubrina, suggesting that its cultivation in a semi-arid environment should be recommended in soils with high $\mathrm{Mg}^{2+}$ content.

\section{ACKNOWLEDGMENTS}

To the Soil Chemistry and Tissue Culture Laboratories and the UFRPE Research Support Center (CENAPESQ) for the infrastructure provided for this research.

\section{REFERENCES}

ALBUQUERQUE, A. S.; FREIRE, F. J.; BARBOSA, M. D.; MARANGON, L. C., FELICIANO, A. L. P. Efficiency of biological utilization of micronutrients by forests species in hypoxerophytic caatinga. Floresta $\mathbf{e}$ Ambiente, Seropédica, v. 25, n. 4, p. 1-10, 2018.

ALVARES, C. A.; STAPE, J. L.; SENTElHAS, P. C.; MORAES GONÇALVES, J. L.; SPAROVEK, G. Köppen's climate classification map for Brazil. Meteorologische Zeitschrift, Stuttgart, v. 22, n. 6, p. 711-728, 2013.

ALVES, A. R.; STAPE, J. L.; SENTELHAS, P. C.; GONÇALVES, J. L. DE M.; SPAROVEK, G. Conteúdo de nutrientes na biomassa e eficiência nutricional em espécies da Caatinga. Ciência Florestal, Santa Maria, v. 27, n. 2, p. 377-390, 2017.

DUARTE, S. DE J.; GLASER, B.; CERRI, C. E. P. Effect of biochar particle size on physical, hydrological and chemical properties of loamy and sandy tropical soils. Agronomy, n.1., v. 9, n. 4, 2019.

FAGERIA, V. D. Nutrient interactions in crop plants. Journal of Plant Nutrition, London, v. 24, n. 8, p. 12691290,2001

GAUTAM, T. P.; MANDAL, T. N. Storage and flux of nutrients in disturbed and undisturbed tropical moist forest of eastern Nepal. International Journal of Forestry Research, n.l., v. 2018, 2018.

GONZÁLEZ-GARCÍA, M.; HEVIA, A., MAJADA, J.,RUBIERA, F.BARRIO-ANTA, M. Nutritional, carbon and energy evaluation of Eucalyptus nitens short rotation bioenergy plantations in northwestern Spain. iForest, Viterbo, n.l., v. 9, n. APR2016, p. 303-310, 2016.

GUIMARÃES, C. C.; SCHUMACHER, M. V.; WITSHORECK, R.; SOUZA, H. P.; SANTO, J. C. Biomassa e nutrientes em povoamento de Eucalyptus dunnii maiden no pampa gaúcho. Revista Árvore, Viçosa-MG, v. 39, n. 5, p. 873-882, 2015.

HOLANDA, A. C., FELICIANO, A. L. P.; MARANGON, L. C.; FREIRE, F. J. HOLANDA, E. M. Decomposição da serapilheira foliar e respiração edáfica em um remanescente de caatinga na Paraíba. Revista Árvore, ViçosaMG, v. 39, n. 2, p. 245-254, 2015.

IBGE. Manual técnico da vegetação brasileira. 2. ed. Rio de Janeiro: IBGE, 2012. v. 39

KIZITO, S.; LUO, H.; LU, J.; BAH, H.; DONG, R.; WU, S. Role of nutrient-enriched biochar as a soil amendment during maize growth: Exploring practical alternatives to recycle agricultural residuals and to reduce chemical fertilizer demand. Sustainability, Basel, n.l., v. 11, n. 11, p. 1-22, 2019.

LEHMANN, J. Bio-Energy in the Black. Frontiers in Ecology and the Environment, Washington D.C., v. 5, p. 381-387, 2007.

LI, J.; WU, G.; GUO, Q.; KORPELAINEN, H.; LI, C. Fast-growing Larix kaempferi suffers under nutrient imbalance caused by phosphorus fertilization in larch plantation soil. Forest Ecology and Management, n.l., v. 417, p. 49-62, 2018.

NANDWA, S. M.; BEKUNDA, M. A. Research on nutrient flows and balances in East and Southern Africa: stateof-the-art. Agriculture, Ecosystems and Environment, n.l., v. 71, p. 5-18, 1998.

SILVA, F. C. DA. Manual de análises químicas de solos , plantas e fertilizantes. 2. ed. Brasília: EMBRAPA Informação Tecnológica, 2009.

SILVA, F. O. R.; MELO, C. C. V.; BOTELHO, H. A.; SOUZA, F. B. M.; J. D. RAMOS. Efeito do resíduo de tanque de piscicultura na produção de mudas de maracujazeiro. Boletim de Indústria Animal, Nova Odessa, v. 
74, n. 1, p. 58-64, 2017.

SOIL SURVEY STAFF. United States Department of Agriculture Keys to Soil Taxonomy. 3. ed. Washington: USDA-Natural Resources Conservation Service, 2014.

TEDESCO, M. J.; GIANELLO, C.; BISSANI, C. A.; BOHNEN, H.; WOLKWEISS, S. J. Análise de solo, plantas e outros materiais. Porto Alegre: Departamento de Solos da Universidade Federal do Rio Grande do Sul., 1995.

TEIXEIRA, M. P.; CAMPOS, C. N. S.; PRADO, R. M. DE; CAIONE, G.; MINGOTTE, F. L. C.; AGOSTINHO, F. B. Microwave drying of plant tissue for nutritional analysis of Corymbia citriodora (hook.) and Hevea brasiliensis muell. Arg. AGROCIENCIA, Montecillo, v. 51, p. 555-560, 2017a.

TEIXEIRA, P. C.; DONAGEMMA, G. K.; FONTANA, A. TEIXEIRA, W. G. Manual de Métodos de Análise de Solo. 3. ed. Rio de Janeiro: EMBRAPA, 2017b.

THEODORO, S. H.; LEONARDOS, O. H.; ROVHA, E.; MACEDO, I.; REGO, K. G. Stonemeal of amazon soils with sediments from reservoirs: A case study of remineralization of the tucuruí degraded land for agroforest reclamation. Anais da Academia Brasileira de Ciências, Rio de Janeiro, v. 85, n. 1, p. 23-34, 2013.

TOLEDO, F. H. S. F. DE; VENTURIN, N.; MACEDO, R. L. G.; DIAS, B. A. S.; SILVA, I. M. M. A.; NEVES, Y. Y. B.; NASCIMENTO, G. DE O.; CARLOS, L. Influência da qualidade química do substrato no teor de nutrientes em folhas de mudas de eucalipto. Ecologia e Nutrição Florestal, Santa Maria, v. 1, n. 2, p. 89-96, 2013.

VEJAN, P.; ABDULLAH, R.; KHADIRAN, T.; ISMAIL, S.; BOYCE, A. N. Role of plant growth promoting rhizobacteria in agricultural sustainability-A review. Molecules, Basel, v. 21, n. 5, p. 1-17, 2016.

VIEIRA, C. R.; WEBER, O. L. DOS S. Produção De Mudas De Eucalipto Em Diferentes Composições De Substratos. Revista de Estudos Ambientais, Blumenau, v. 18, n. 2, p. 25, 2017.

VIERA, M.; BONACINA, D. N.; SCHUMACHER, M. V.; CALIL, F. N.; CALDEIRA, M. V. W.; WATZLAWICK, L. F. Biomassa e nutrientes em povoamento de Eucalyptus urograndis na Serra do Sudeste-RS. Semina:Ciencias Agrarias, Londrina, v. 33, n. 1, p. 2481-2490, 2012. 